\title{
Applied methods of exercise based therapy for the extension of walking distance in patients with intermittent claudication
}

\author{
Wojciech Pasiak', Anna Stelmach², Agnieszka Zdzienicka-Chyla ${ }^{3}$, Marek Banbula ${ }^{4}$, \\ Tomasz Zubilewicz' \\ 'Chair and Department of Vascular Surgery and Angiology, Medical University of Lublin, Poland \\ ${ }^{2}$ Division of Rehabilitation and Physiotherapy, Department of Rehabilitation, Physiotherapy and Balneotherapy, \\ Medical University of Lublin, Poland \\ ${ }^{3}$ Division of Physiotherapy, University Children's Hospital in Lublin, Poland \\ ${ }^{4}$ Dalriada Urgent Care, United Kingdom of Great Britain and Northern Ireland
}

\begin{abstract}
Intermittent claudication, according to the Fontaine Classification Scale is a symptom of $2^{\text {nd }}$ degree atherosclerosis of the arteries of the lower limbs. The process of atherosclerosis involves increased narrowing of the blood vessel lumina and their eventual closure. Patients with atherosclerosis often suffer bouts of muscular pain while walking which eventually leads to restricted mobility. The treatment of those affected by furring up of the arteries of the lower limbs includes intravascular procedures, insertion of balloon devices and stents and in severe cases of atherosclerosis surgical intervention is required. The more conservative areas of treatment involve pharmacotherapy, patient participation in educational training sessions, lifestyle changes and appropriate physiotherapy referrals. If applied early on, lifestyle changes such as smoking cessation, an improved diet, as well as targeted training can help avoid the need for surgical intervention. At the moment, the goal of mainstream physiotherapy in the treatment of peripheral artery disease is to determine the most appropriate forms of exercise which can increase the walking distance of patients with intermittent claudication, improve blood-flow in particular to the lower extremities as well as improve patients' overall quality of life. The purpose of this study is to gather and analyse exercise strategies that result in increased walking distance in intermittent claudication. The best results have been observed in groups who teamed up ambulatory therapy with strength training; Nordic walking therapy along with strength training and finally walking training with upper body aerobic training on the cross-trainer. The variety of training combinations gives us the ability to cater for and accommodate individual patient needs.
\end{abstract}

Key words: intermittent claudication, ambulatory training, resistance training, cross-trainer training

Acta Angiol 2017; 23, I: 25-28

\section{Introduction}

Intermittent claudication according to the Fontaine Classification Scale is a symptom of $2^{\text {nd }}$ degree atherosclerosis of the lower limbs. The main atheromatous processes lead to narrowing and eventual closure of the arteries. Walking involves all muscles all over the body from the lower limbs to the pelvis, torso and upper limbs. Walking is accompanied by increased oxygen demand. Patients with lower limb artery furrowing

Address for correspondence: Wojciech Pasiak, Chair and Department of Vascular Surgery and Angiology Medical University of Lublin, Staszica I I, 20-08I Lublin, Poland, e-mail: wojciechpasiak@vp.pl 
experience restricted blood supply to the actively working muscles. Muscles starved of their blood supply will start to produce pain as well as cause restricted movement [I].

The basic elements of treatment involve the carrying out of various forms of exercise which increase the walking distance in intermittent claudication. Various forms of exercise have been documented. Ambulatory training (supervised and unsupervised) cross-trainer training, nordic walking and resistance training.

The objective of physical training in patients with intermittent claudication is to increase the walking distance before symptoms of claudication appear, increase muscle strength, improve the functioning of the cardiovascular system as well as improving patient quality of life. The main mechanisms in effectiveness of these interventions are improved functioning of the endothelium, creation of collateral circulation, improved blood-flow, changes in ischaemic related pain perception and halting further atherosclerotic deterioration [2].

\section{Ambulatory training}

Ambulatory training in patients with atherosclerosis of the lower limbs has been found to reduce symptoms as well as to increase physical efficiency [3]. In accordance with the TransAtlantic Intersociety Consensus II (TASC II) guidelines ambulatory training should be carried out in an interval based format. The walking activity should be suspended at the first sign of moderate pain symptoms. The effort used in the activity should be regulated by increasing the gradient on the treadmill or its speed [4].

Ambulatory therapy is a popular and relatively cheap method of physiotherapy for patients with peripheral vascular disease. The exercises can be done under practitioner supervision or without supervision (at the patient's own home.) Numerous clinical trials have proven the effectiveness of supervised physiotherapy in increasing walking distance in patients with intermittent claudication as well as increasing patient quality of life [5]. An analysis of fourteen studies in which 1002 patients took part compared the effectiveness of supervised therapy against unsupervised, and showed definitive superior results in the former group. There was a clear increase in pain-free walking distance in intermittent claudication patients of approximately 180 metres that took part in supervised physiotherapy session compared to those who exercised at home [6].

A period of six months of supervised ambulatory therapy has been seen to result in improved gait as well as increased lipid metabolism and decreased oxygen consumption during submaximal exertion. Supervised training leads to the appearance of morphological changes in the femoral artery, increased blood flow as well as the development of collateral circulation [7-10].

Patients with intermittent claudication often exhibit disturbed walking patterns, specifically disturbances in the phases of gait, the phase whereby one foot is on the ground supporting the body is shortened and the alternate phase during which both feet are in contact with the ground becomes abnormally lengthened. This could be in response to disturbances in muscular-nerve control related to the increased focussing on stability [I].

Ambulatory therapy results in improvement in the biomechanics of gait. Following a 12-week training program, longer stride length was observed, reduced number of steps taken and the gait became more regular and efficient [II, I2].

The greatest change in gait measurements are observed during the supportive phase. Patients carry out intense plantar flexion in the ankle joint as the heel is in contact with the floor/ground. An increase in plantar flexion along with correct dorsal flexion during this phase results in an increased range of movement in the ankle joint. These changes have been observed both before and after incidences of lower limb pain [13, 14].

\section{Resistance training}

Resistance training can lead to an increase in walking distance in intermittent claudication, increased muscle mass as well as improved patient quality of life [15-17]. During twelve weeks of resistance training following which increases in muscle mass were observed in the muscles of the lower limbs (quadriceps, hamstrings, the anterior tibialis, the triceps surae as well as the hip abductors and adductors). The training is carried out in three sets of 15 repetitions, the load was increased by $5 \%$ and individually adjusted to the abilities of the patient. The second group underwent ambulatory therapy. Both groups achieved similar results when it came to the maximum intermittent claudication distance.

Strength training, like ambulatory training caused a decrease in cardio-vascular incidents, improved respiratory function and increased oxygen efficiency as well as superior gait [17].

\section{Nordic walking}

Nordic walking therapy involves not only the use of the muscles of the lower limbs but also those of the torso and upper limbs. Nordic walking exercises can improve oxygen efficiency as well as cardio-vascular functioning. Tests which compared traditional ambulatory therapy with Nordic walking therapy demon- 
strated that walking with sticks has a positive effect on improving intermittent claudication distance, walking speed in spite of greater loads as well as more effective cardio-vascular functioning [17-20].

\section{Training bike exercise}

Exercises using training bike can be an alternative for traditional march conducted using treadmill. Research comparing both forms of training did not show major differences in extending the walking distance in patients with intermittent claudication. The walking distance increased about the same in both groups [2I]. Exercising using a training bike allows to reduce rest time required and increase the strain of the exercise. Pain-free method of exercise on a training bike does not cause the inflammation [22, 23].

\section{Mixed exercise}

In order to increase intermittent claudication distance a combination of various exercise methods can be employed. Studies in which during a 12-month period traditional ambulatory therapy was carried out alongside strength training resulted in a marked increase in intermittent claudication distance, improvements in walking speed as well as increased indicators of muscle strength [22]. Comparisons between treadmill training and Nordic walking training and strength-stamina training proved that strength and cardio training was the most effective. It leads to a greater degree of increase in intermittent claudication distance as well as increases in muscle flexor strength as well as the quadriceps femoris extensor muscles as well as the extensors and flexors of the ankle joint [17].

The aerobic cross trainer exercise program which employed the upper limbs leads to an increase in intermittent claudication distance and cardio-vascular improvements. Patients who were prescribed this form of training in conjunction with ambulatory training showed a superior tolerance to exertion as well as improvements in gait cycle performance [24-27].

\section{Conclusion}

Physiotherapy is currently looking for exercise treatment programs in cases of peripheral vascular disease which result in an increased intermittent claudication distance, lead to improvements in blood flow especially to the lower extremities as well as improving patient quality of life. Many training methods allow us to increase the intermittent claudication distance as well as increase patient quality of life. The best results have been recorded in study groups who combined ambulatory training with strength training; Nordic walking training with strength training, ambulatory training with aerobic cross-trainer training. The variety of forms of training available give us the ability to prescribe a form which is catered to the needs of the patient. It is important that in addition to the appropriate physiotherapy treatment that the patient engages in educational programs with a view to improving their overall lifestyle.

\section{References}

I. Konik A, Mika P, Nowobilski R, et al. Mechanizm responsible for reducing intermittent claudication as a result of treadmill training. Acta Angio. 2010; 16: 49-66.

2. Bulińska K, Kropielnicka K, Jasiński T, Skórkowska-Telichowska K, Pilch K. Kompleksowa rehabilitacja pacjentów z chromaniem przestankowym w przewlekłym niedokrwieniu kończyn dolnych. Fizjoterapia. 20I2; 4: 3-16.

3. Tendera M, Aboyans V, Bartelink M-L, et al. Wytyczne dotyczące rozpoznania i leczenia chorób tętnic obwodowych. Kardiol Pol. 20II; 69: 27I-340.

4. Norgen L, Hiatt WR, Dormandy JA, et al. on behalf of the TASC II Working Group Inter society consensus for the management of peripheral arteria disease. (TASC II). Eur J Vasc Endovasc Surg. 2007; 33: I-70.

5. Szymczak M, Majchrzycki M, Stryła W, et al. The effects of various form of rehabilitation on patients with lower limb ischemia. Trends in Sport. 2014; 2: 93-100.

6. Melton $C$. Supervised exercise program helps patiens with peripheral artery disease walk longer. Clinical Geriatrics. 20II; 19: I-17.

7. Fokkenrood HJP, Bendermacher BLW, Lauret GJ, et al. Supervised exercise therapy versus non-supervised exercise therapy for intermittent claudication. Cochrane Database Syst Rev. 2006(2): CD005263, doi: 10.1002/1465/858.CD005263.pub2, indexed in Pubmed: 16625633.

8. Crowther RG, Leicht AS, Spinks WL, et al. Effects of a 6-month exercise program pilot study on walking economy, peak physiological characteristics, and walking performance in patients with peripheral arterial disease. Vasc Health Risk Manag. 2012; 8: 225 232, doi: 10.2147/VHRM.S30056, indexed in Pubmed: 22566743.

9. McDermott MM, Liu K, Guralnik JM, et al. Home-based walking exercise intervention in peripheral artery disease: a randomized clinical trial. JAMA. 2013; 310(1): 57-65, doi: 10.1001/ jama.2013.7231, indexed in Pubmed: 23821089.

10. Guidon M, McGee H. One-year effect of a supervised exercise programme on functional capacity and quality of life in peripheral arterial disease. Disabil Rehabil. 2013; 35(5): 397-404, doi: 10.3109/09638288.2012.694963, indexed in Pubmed: 22804715.

II. Leicht AS, Crowther RG, Golledge J. Influence of peripheral arterial disease and supervised walking on heart rate variability. J Vasc Surg. 201 I; 54(5): 1352-1359, doi: 10.1016/j. jvs.2011.05.027, indexed in Pubmed: 21784603.

12. Dopheide JF, Rubrech J, Trumpp A, et al. Supervised exercise training in peripheral arterial disease increases vascular shear stress and profunda femoral artery diameter. Eur J Prev Car- 
diol. 2017; 24(2): |78-19|, doi: 10.|177/20474873|6665231, indexed in Pubmed: 27550906.

13. Thiede R, Toosizadeh N, Mills JL, et al. Gait and balance assessments as early indicators of frailty in patients with known peripheral artery disease. Clin Biomech (Bristol, Avon). 2016; 32: I-7, doi: 10.1016/j.clinbiomech.2015.12.002, indexed in Pubmed: 26775227.

14. Celis R, Pipinos II, Scott-Pandorf MM, et al. Peripheral arterial disease affects kinematics during walking. J Vasc Surg. 2009; 49(I): 127-132, doi: 10.1016/ij.jvs.2008.08.013, indexed in Pubmed: 19028062.

15. Wang E, Helgerud J, Loe $\mathrm{H}$, et al. Maximal strength training improves walking performance in peripheral arterial disease patients. Scand J Med Sci Sports. 2010; 20(5): 764-770, doi: 10.1111/1.1600-0838.2009.01014.x, indexed in Pubmed: 19804581.

16. Grizzo Cucato G, de Moraes Forjaz CL, Kanegusuku H, et al. Effects of walking and strength training on resting and exercise cardiovascular responses in patients with intermittent claudication. Vasa. 20II; 40(5): 390-397, doi: 10.1024/030I-|526/ a000136, indexed in Pubmed: 21948782.

17. Kropielniecka K. Kropielniecka K. Wpływ wybranych form treningowych na czynność mięśni kończyn dolnych I tolerancję wysiłku u pacjentów z chromaniem przestankowym. Praca doktorska. 2013.

18. Szymczak M, Oszkinis G, Majchrzycki M. The Impact of Walking Exercises and Resistance Training upon the Walking Distance in Patients with Chronic Lower Limb Ischaemia. Biomed Res Int. 2016; 2016: 7515238, doi: 10.1155/2016/7515238, indexed in Pubmed: 27833919.

19. Collins EG, McBurney C, Butler J, et al. The Effects of Walking or Walking-with-Poles Training on Tissue Oxygenation in Patients with Peripheral Arterial Disease. Int J Vasc Med. 2012; 2012: 985025, doi: $10.1155 / 2012 / 985025$, indexed in Pubmed: 23050152
20. Collins EG, O connell S, McBurney C, et al. Comparison of walking with poles and traditional walking for peripheral arterial disease rehabilitation. J Cardiopulm Rehabil Prev. 2012; 32(4): 210-218, doi: 10.1097/HCR.0b0/3e31825828f4, indexed in Pubmed: 22595894.

21. Kowalski R. Porównanie efektów treningu na biezni ruchomej $z$ treningiem na cykloergometrze rowerowym u pacjentów z miażdżycą tętnic dolnych. Praca doktorska. 2007.

22. Dedes H, Figoni S, Kalioundji G, et al. Poster 42: Prospective Trial of Calf Ergometry Training on Walking Ability in Peripheral Arterial Disease. PM\&R. 2010; 2(9): S26, doi: 10.1016/j. pmri.2010.07.072.

23. Kowalski R, Jasiak-Tyrkalska B, Brzostek T, et al. Porównanie efektu na bieżni ruchomej $z$ treningiem na cykloergometrze rowerowym - doniesienia wstępne. Fizjoterapia Polska. 2007; 7: 438-436.

24. Bronas UG, Treat-Jacobson D, Leon AS. Comparison of the effect of upper body-ergometry aerobic training vs treadmill training on central cardiorespiratory improvement and walking distance in patients with claudication. J Vasc Surg. 201 I; 53(6): 1557-1564, doi: 10.1016/j.jvs.2011 .01.077, indexed in Pubmed: 21515017 .

25. Treat-Jacobson D, Bronas UG, Leon AS. Efficacy of arm-ergometry versus treadmill exercise training to improve walking distance in patients with claudication. Vasc Med. 2009; 14(3): 203-213, doi: 10.1177/1358863×08101858, indexed in Pubmed: 19651669.

26. Treat - Ja, Bronas UG, Krause BJ, et al. erobic arm exercise training to improve outcomes for patients with severe claudication and ischemic rest pain. Vascular Medicine. 2012; 17: 204.

27. Walker RD, Nawaz S, Wilkinson $\mathrm{CH}$, et al. Influence of upper- and lower-limb exercise training on cardiovascular function and walking distances in patients with intermittent claudication. J Vasc Surg. 2000; 31(4): 662-669, doi: 10.1067/ mva.2000.104104, indexed in Pubmed: 10753273. 